\title{
MECHANICKÁ FILTRACE PRO ČIŠTĚNÍ ŠEDÝCH ODPADNÍCH VOD
}

\author{
GREYWATER TREATMENT BY MEMBRANE AND SAND FILTRATION
}

\author{
Kristýna Velikovská*,1
}

"velikovska.k@fce.vutbr.cz

${ }^{1}$ Vysoké učení technické v Brně: Fakulta stavební, Ústav vodního hospodářství obcí, Veveří 331/95, 60200 Brno

\begin{abstract}
Abstrakt
Šedá odpadní voda je významnou složkou městských odpadních vod, přičemž její úroveň znečištění z pohledu fyzikálních, chemických i mikrobiologických ukazatelů je významně nižší než znečištění černých, popř. splaškových odpadních vod. Z pohledu udržitelného hospodaření s vodou je proto čištění šedých odpadních vod efektivním přístupem $\mathrm{k}$ jejich opětovnému využívání. Tento příspěvek se zabývá čištěním šedé vody vybranými filtračními technologiemi a výsledky z provedeného testování pískové filtrace $\mathrm{v}$ laboratorních podmínkách a aplikace mikrofiltrační a ultrafiltrační membránové jednotky v reálných podmínkách rodinného domu.
\end{abstract}

\section{Klíčová slova}

Recyklace odpadní vody, šedá voda, bílá voda, písková filtrace, membránová filtrace

\begin{abstract}
Greywater reuse is a significant part of urban wastewater with low values of physical, chemical and microbiological pollution indicators. Therefore, reusing greywater is an effective approach of sustainable water management. This paper deals with greywater treatment membrane methods leading to reusing greywater, presenting obtained values of testing sand filtration and microfiltration and ultrafiltration membrane modules.
\end{abstract}

Key words

Wastewater reuse, greywater, white water, sand filtration, membrane filtration

\section{1 ÚVOD}

Současný trend udržitelného hospodaření nejen s vodními zdroji je celosvětově diskutované téma zaměřené na ekologické, energetické a ekonomické přístupy reagující na neustávající poptávku po vodních i energetických zdrojích, způsobenou klimatickými změnami, růstem populace a rychlou urbanizací. Významný důraz v neustávajícím rozvoji je kladen uplatňováním environmentální certifikace budov, mezi které patří např. Leadership in Energy and Environmental Design (LEED) nebo Building Research Establishment Environmental Assessment Method (BREAM) a jiné, jenž hodnotí udržitelnost stavby z pohledu sociálních a kulturních aspekti̊, ekonomické efektivity a životního prostředí. Hodnocení z hlediska životního prostředí je založeno také na sledování kritéria spotřeby vody.[1] Klíčovým řešením k snížení spotřeby pitné vody a efektivnímu nakládání s vodou může být opětovné využití odpadní vody.

K opětovnému využívání odpadní vody již na úrovni objektů určených k bydlení, průmyslových objektů, sportovišt' a wellness, nebo obecně objektů s vysokou produkcí odpadní vody, lze využít šedé složky odpadní vody. Šedá odpadní voda je složkou městských odpadních vod, jejíž zdrojem jsou koupelny, umyvadla a dřezy, pračky a myčky nádobí.[2] Tedy přibližně 70 \% z celkové produkce odpadní vody v domácnosti tvoří voda šedá, zbylých $30 \%$ produkce je pak zastoupena černou odpadní vodou.

Využívání šedé odpadní vody je však podmíněno aplikací vhodných technologických procesů čištění a splnění legislativně stanovených pokynů k opětovnému využívání OV. V roce 2020 byla v České republice vydána technická norma ČSN ISO 20761 Opětovné využití vody v městských oblastech - směrnice pro hodnocení bezpečnosti opětovného využití vody - hodnocené ukazatele a metody [3] popisující zmíněné pokyny a limity předepisující kvalitu vyčištěné vody $\mathrm{v}$ závislosti na typu dalšího využití.

Předmětem tohoto příspěvku je představení použitých filtračních technologií a výsledků z provedeného testování pískové filtrace $\mathrm{v}$ laboratorních podmínkách a aplikace mikrofiltrační a ultrafiltrační membránové 
jednotky v reálných podmínkách rodinného domu. Výsledky z testování jsou v příspěvku vztaženy k platné legislativě předepisující limity znečištění pro kvalitu odpadní vody určenou k opětovnému využití.

\section{FILTRAČNÍ TECHNOLOGIE PRO ČIŠTĚNÍ ŠEDÝCH VOD}

Technologický proces čištění šedých OV k jejich následnému opětovnému využití za splnění doporučených kritérií lze čištění sestavit z fyzikální (mechanické), chemické nebo biologické úpravy vody, využití prrírodních čistících postupů, príípadně jejich kombinací.

Nejvyužívanějším způsobem mechanického čištění odpadních vod je proces filtrace. Předmětem této kapitoly je představení vybraných filtračních procesů, které byly podrobeny testování, a tedy aplikaci pro čištění šedé vody.

V kapitole je představena písková filtrace, jejíž významnou výhodou je jednoduchý provoz, jednoduchá údržba a nízké investiční a provozní náklady. Samotné zařazení pískové filtrace do technologického procesu čištění však nezaručuje plné odstranění patogenů z odpadní vody.

Dále je v rámci kapitoly představena membránová filltrace odstraňující z vody rozpuštěné i nerozpuštěné látky. Membrány jsou schopny odstranit znečištění v závislosti na svých parametrech, a to zejména na rozměrech částic, které jsou schopny zachytit.

Oba systémy mechanického čištění je vhodné doplnit o zařazení hygienického zabezpečení před samotným využitím permeátu. $V$ prrípadě využití permeátu jako zdroj šedé vody je důležité zařadit do čistícího procesu stupeň hygienického zabezpečení. Pro hygienické zabezpečení lze využít chemických nebo fyzikálně chemických přístupů, tedy např́ílad ve formě zařazení UV lampy, případně ozonizační nebo chlorační jednotky [5],[6]. Nejvyužívanějším prrístupem k hygienickému zabezpečení odpadních vod je dezinfekce dávkováním chlornanu sodného.

\section{Písková filtrace}

Písková filtrace zahrnuje základní fyzikální čistící proces založený na adsorpci nerozpuštěných látek na filltračním loži, tj. pískovém filtru. Jedná se o tzv. filtraci objemovou, tedy filtraci přes vrstvu zrnitého materiálu [4].

Písková filtrace systému využití šedých vod může být použita samostatně nebo také v kombinaci s dezinfekcí anebo aktivním uhlí. Filtrační materiál může být z křemičitého písku, granulovaného aktivního uhlí GAC, antracitu a jeho volba a frakce je závislá na složení čištěné šedé vodě [4], [5].

Jako filtrační materiál může také být zvoleno dostupné lehké keramické kamenivo Liapor, vyrobené výpalem a expandací třetihorních jílů v rotačních pecích. Výpalem tak vznikají keramické kuličky s porézní strukturou a slinutým povrchem o průměru 1-16 mm. Liapor slouží v čistících procesech jako pevné lože - usazovací základ pro mikroorganismy. V Liaporovém filtračním loži tak dochází k fyzikálnímu, chemickému i biologickému čištění odpadní vody (prostřednictvím biofilmu).

Účinnost pískové filtrace lze dále podpořit přerušovanou filtrací a aerací, která podporuje růst mikroorganismů schopných absorbovat a odstranit patogenní látky i jemné koloidní částice. Při provozování čistící technologie systému využití šedých vod je potřeba sledovat vrstvu biofilmu vytvořenou na pískovém loži, dále je potřeba zajistit dostatečný prrísun živin formou šedé vody a eliminovat nadměrné prrítoky odpadní vody určené k čištění $[4],[5]$.

\section{Membránová filtrace}

Membránové procesy čištění vod jsou založené na principu polopropustnosti, tzv. semipermeability. Zařazením membrány do prostředí vzniká bariéra separující nečistoty, také nazývané jako retentát, a propouštějící přečištěnou vodu, tzv. permeát [6]. Proces úpravy vody pomocí membrán lze provést jako jednoduchou fyzikální filltraci nebo filtraci s biologickou úpravou [5].

Membránovou filtraci je vhodné doplnit předřazeným mechanickým předčištěním pro zvýšení její účinnosti a životnosti. Jako mechanické předčištění lze zvolit např. filtraci s pískovou náplní nebo granulovaným aktivním uhlím [5].

Membránové technologie lze rozdělit do kategorií dle velikosti pórů, respektive na základě minimální velikosti částic, které jsou schopny zachytit na povrchu membrány. Membránové procesy tedy dělíme, s přihlédnutím k obrázku Obr. 1 následovně:

- $\quad$ mikrofiltrace (MF);

- ultrafiltrace (UF);

- $\quad$ nanofiltrace (NF); 
- reverzní osmóza $(\mathrm{RO})[5]$.

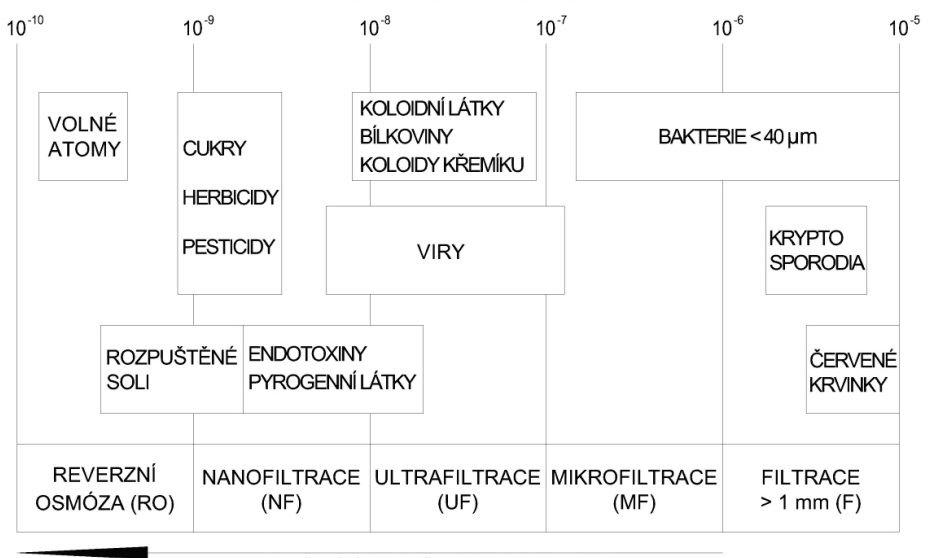

ZVYŠUJICI SE POŽADAVEK NA ENERGI

Obr. 1 Rozdělení membránových procesů vztažené na velikost separovaných částic a organismů [5].

\section{METODIKA}

Testování srovnávaných filtračních technologií probíhalo v rámci řešení juniorského specifického projektu "Aktuální přístupy k čištění odpadních vod" a projektu " Získávání a využití tepelné energie z odpadní vody v kombinaci s využitím vyčištěné vody" ve třech etapách:

- Testování pískové filtrace pro čištění šedé vody ze sprchování v laboratoři výzkumného centra AdMaS,

- Testování membránové mikrofiltrace pro čištění šedé neseparované vody v rodinném domě,

- Testování membránové ultrafiltrace pro čištění šedé neseparované vody v rodinném domě.

Při čištění šedé vody pískovou filtrací byla šedá OV přečerpávána přes svíčkový filltr do perforovaného rozdělovacího potrubí pro zajištění rovnoměrného průtoku po celé ploše otevřeného rychlofiltru. Samotná filtrace pak probíhala přes sorpční náplň z materiálu Keramzit Liapor (frakce 1-4 mm). V průběhu testování nebyla filtrační náplň regenerována. Pro odběr bílé vyčištěné vody (permeátu) sloužila odtoková akumulační komora s odtokem a odkalovacím hrdlem.

V rámci druhé etapy byla ověřována účinnost čištění šedé vody mikrofiltrační membránové jednotky $\mathrm{v}$ rodinném domě $\mathrm{s}$ mechanickým předčištěním šedé vody $\mathrm{v}$ předřazené akumulační nádrži s nornou stěnou. Pro testování byla použit membránový modul sestavený z 1600 polyethylenových dutých membránových vláken o průměru $0,41-0,44 \mathrm{~nm}$ s průlinami $0,02 \mu \mathrm{m}$.

Testování pískové filtrace a mikrofiltrační membrány však nepřineslo výsledky splňující limity v plném rozsahu s ohledem na využití šedé odpadní vody pro účely splachování toalet nebo zavlažování. Závěry z ukončeného testování aplikované mikrofiltrační jednotky v reálných podmínkách předpokládaly dosažení normativně (ČSN ISO 20761 [1]) stanovených limitů pro vyčištěnou bílou vodou pro instalaci ultrafiltrační membrány.

Ve třetí etapě byla tedy nahrazena mikrofiltrační membrána membránou ultrafiltrační. Ultrafiltrační jednotka je založena na filtraci přes deskové membrány s průlinami membrán do $10 \mathrm{~nm}$. Testování třetí etapy v době odevzdání př́íspěvku stále probíhá a její ukončení je naplánováno do konce roku 2021.

V Tab. 1 jsou představeny kritéria kvality vody pro opětovné použití vyčištěné odpadní vody dle normy ČSN ISO 20761. Srovnání získaných výsledků měření je znázorněno v Tab. 2. Testování jednotlivých technologií bylo zaměřeno na následující ukazatele kvality vody:

- ukazatel pH ovlivňující většinu fyzikálně-chemických, chemických a biochemických procesů ve vodách, který je definovaný jako záporný logaritmus látkové koncentrace vodíkových iontů;

- $\quad$ hodnoty ukazatele barvy, které byly měřeny nezávisle na odstínu a sytosti barvy vzorku, odpovídají měřítku Amerického institutu výrobců barviv ADMI, který použivá platino-kobaltový standard, jako standard pro barevnou hodnotu; 
- ukazatel zákalu neboli snížení průhlednosti vody nerozpuštěnými látkami, byl stanoven porovnáním se standardní formazinové suspenze spektrofotometrickým měřením procházejícího záření. Zákal je vyjádřen v jednotkách ZF(n), která odpovídá výsledku měření zákalu formazinem nefelometricky (metodou měření rozptýleného záření). Jednotky ZF(n) lze označit také FNU (Formazine Nephelometric Unit) a odpovídají 1 FNU=1 FTU (Formazine Turbidity Unit) $=1$ NTU (Nephelometric Turbidity Units) =0,25 EBC (European Brewery Convention);

- ukazatel biochemické spotřeby kyslíku (BSK5) definuje hmotnostní koncentraci rozpuštěného kyslíku spotřebovaného za určitých podmínek $\mathrm{k}$ biochemické oxidaci organických, popř́ípadě anorganických látek ve vodě během inkubační doby pěti dnů;

- ukazatel CHSKCr (chemická spotřeba kyslíku) vyjadřuje množství kyslíku pocházejícího z dichromanu draselného, které je za přesně definovaných podmínek potřebné pro oxidaci organických látek; vzorky vody byly v rámci analýzy oxidovány horkým sirným roztokem dichromanu draselného, za použití síranu stříbrného jako katalyzátoru;

- ukazatel nerozpuštěných látek (NL), neboli suspendovaných látek, představuje výskyt tuhých látek odstranitelných filtrací [2], [7].

Rozbory vzorků odpadní vody pro analýzu barvy, zákalu, BSK $_{5}$ a NL byly prováděny na Fakultě chemické, Vysokého učení technického v Brně. Pro stanovení ukazatele $\mathrm{pH}$ byl využíván digitální multiparametrový měřič inoLab® Multi 9430 v laboratoři výzkumného centra AdMaS.

Tab. 1 Kritéria kvality vody a směrnice pro využití k splachování toalet v několika zemích [2] (pozn.: med=medián, $\max =$ maximum).

\begin{tabular}{|c|c|c|c|c|c|c|c|}
\hline \multirow{2}{*}{ Ukazatel } & \multirow{2}{*}{ m.j. } & \multicolumn{6}{|c|}{ Kritéria kvality bílé vody pro splachování toalet dle jednotlivých zemí } \\
\hline & & Kanada & Čína & Izrael & Japonsko & Španělsko & USA \\
\hline $\mathrm{pH}$ & - & - & $6,0-9,0$ & $6,5-8,5$ & $5,8-8,6$ & - & $6,0-9,0$ \\
\hline Barva & $\mathrm{Pt} \cdot \mathrm{Co}^{-1}$ & - & $\leq 30$ & - & - & - & - \\
\hline Zákal & NTU & $\begin{array}{l}\leq 2(\text { med }) \\
\leq 5(\max )\end{array}$ & $\leq 5$ & $\begin{array}{l}\leq 2(\text { med }) \\
\leq 5(\max )\end{array}$ & - & $\leq 2$ & $\leq 2$ \\
\hline $\mathrm{BSK}_{5}$ & $\mathrm{mg} \cdot \mathrm{l}^{-1}$ & $\begin{array}{l}\leq 10(\text { med }) \\
\leq 20(\max )\end{array}$ & $\leq 10$ & $\leq 10$ & - & - & $\leq 10$ \\
\hline NL & $\mathrm{mg} \cdot \mathrm{l}^{-1}$ & $\begin{array}{l}\leq 10(\text { med }) \\
\leq 20(\max )\end{array}$ & - & - & - & $\leq 10$ & - \\
\hline
\end{tabular}

Tab. 2 Kritéria kvality vody a směrnice pro využití k zavlažování v několika zemích [2] (pozn.: med=medián, $\max =$ maximum).

\begin{tabular}{|c|c|c|c|c|c|c|}
\hline \multirow[b]{2}{*}{ Ukazatel } & \multirow[b]{2}{*}{ m.j. } & \multicolumn{5}{|c|}{ Kritéria kvality bílé vody k zavlažování dle jednotlivých zemí } \\
\hline & & Čína & $\begin{array}{c}\text { Izrael } \\
\text { (neomezená } \\
\text { oblast) }\end{array}$ & $\begin{array}{c}\text { Izrael } \\
\text { (omezená } \\
\text { oblast) }\end{array}$ & Japonsko & $\begin{array}{c}\text { USA } \\
\text { (omezená } \\
\text { oblast) }\end{array}$ \\
\hline $\mathrm{pH}$ & - & $6,0-9,0$ & $6,5-8,5$ & $6,5-8,5$ & $5,8-8,6$ & $6,0-9,0$ \\
\hline Barva & $\mathrm{Pt} \cdot \mathrm{Co}^{-1}$ & $\leq 30$ & - & - & $\leq 40$ & - \\
\hline Zákal & NTU & $\leq 10$ & $\begin{array}{l}\leq 2(\text { med }) \\
\leq 5(\max )\end{array}$ & $\begin{array}{l}\leq 2(\text { med }) \\
\leq 10(\max )\end{array}$ & - & - \\
\hline Zákal & $\begin{array}{c}\mathrm{mg} \cdot \mathrm{l}^{-1} \\
\text { kaolinu }\end{array}$ & - & - & - & $\leq 2$ & - \\
\hline BSK5 & $\mathrm{mg} \cdot \mathrm{l}^{-1}$ & $\leq 20$ & $\leq 10$ & $\leq 10$ & - & $\leq 30$ \\
\hline NL & $\mathrm{mg} \cdot \mathrm{l}^{-1}$ & - & - & - & - & $\leq 30$ \\
\hline
\end{tabular}




\section{VÝSLEDKY A DISKUZE}

Výsledky rozborů odebraných vzorků z testování filtračních technologií jsou znázorněny v Tab. 3. Hodnoty analyzovaných ukazatelů kvality OV jsou vždy uvedeny pro prítok ŠV do technologického procesu a odtok vyčišstěné BV. Výsledky pro vzorky PF 1-10 (resp. čísla vzorků 1-5) představují vyčištěné šedé vody (bílé vody) na výstupu z pískové filtrace, vzorky MF 1-10 (resp. čísla vzorků 6-10) představují vyčiššěné šedé vody (bílé vody) na výstupu z mikrofiltrace, vzorky UF 1-2 (resp. číslo vzorků 11) představují výsledky vyčištěné šedé vody (bílé vody) na výstupu z ultrafiltrace. Hodnoty ukazatelů označené "n" nebyly stanoveny.

Tab. 3 Výsledky analýzy šedé odpadní vody a filtračními technologiemi vyčištěné bílé vody.

\begin{tabular}{|c|c|c|c|c|c|c|c|c|c|c|c|c|c|c|c|}
\hline \multirow{3}{*}{ Č. } & el & \multirow{2}{*}{\multicolumn{2}{|c|}{$\mathrm{H}$}} & \multirow{2}{*}{\multicolumn{2}{|c|}{$\begin{array}{l}\text { barva } \\
\mathrm{Pt}^{-\mathrm{CO}^{-1}}\end{array}$}} & \multirow{2}{*}{\multicolumn{2}{|c|}{$\begin{array}{l}\text { zákal } \\
\text { ZF(n) }\end{array}$}} & \multirow{2}{*}{\multicolumn{2}{|c|}{$\frac{\mathrm{NL}}{\mathrm{mg} \cdot \mathrm{l}^{-1}}$}} & \multirow{2}{*}{\multicolumn{2}{|c|}{$\frac{\mathrm{BSK}_{5}}{\mathrm{mg} \cdot \mathrm{I}^{-1}}$}} & \multirow{2}{*}{\multicolumn{2}{|c|}{$\begin{array}{r}\mathrm{CHSK}_{\mathrm{Cr}} \\
\mathrm{mg} \cdot \mathrm{l}^{-1}\end{array}$}} & \multirow{2}{*}{\multicolumn{2}{|c|}{$\begin{array}{r}\begin{array}{r}\text { tenzidy } \\
\text { (aniont) }\end{array} \\
\mathrm{mg} \cdot \mathrm{l}^{-1}\end{array}$}} \\
\hline & MJ & & & & & & & & & & & & & & \\
\hline & OV & ŠV & BV & $\check{\text { ŠV }}$ & BV & ŠV & BV & ŠV & BV & ŠV & BV & ŠV & BV & ŠV & BV \\
\hline 1 & PF 1,2 & 8, & & 1 & & & & & & & & & & 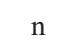 & 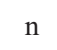 \\
\hline 2 & & & & 2 & & & & -1 & & & & & & & 11 \\
\hline 3 & & & & 2 & & & & 6 & & & & 69 & & $\mathrm{n}$ & $\mathrm{n}$ \\
\hline 4 & & & 8 & 3 & & 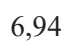 & & (3) & & & 0 & & & $\mathrm{n}$ & $\mathrm{n}$ \\
\hline 5 & & & & 9 & & & & 77 & & & & & & $\mathrm{n}$ & $\mathrm{n}$ \\
\hline 6 & & & & & & & & & & & & & & 30,5 & 0,5 \\
\hline 7 & $\mathrm{~N}$ & 7,80 & 8 & & 75 & 323 & & 33 & 19 & & & & & 6,1 & 0,4 \\
\hline 8 & & $\mathrm{n}$ & & 28 & & & & 4 & & & & & & 7,6 & 0,4 \\
\hline 9 & $\mathrm{~N}$ & $\mathrm{n}$ & 7,8 & 14 & 8 & 12,4 & & 21 & , & & & & & 6,2 & 0,4 \\
\hline 10 & & $\mathrm{n}$ & 8,30 & $>225$ & 190 & 36 & & 30 & 7 & & 16,5 & 196 & 87 & 6,1 & 0,4 \\
\hline 11 & UF 1,2 & $\mathrm{n}$ & $\mathrm{n}$ & $\mathrm{n}$ & $\mathrm{n}$ & 50,2 & 1,35 & 68 & 7 & 80,0 & 4,8 & 223 & 40 & 7,9 & 0,3 \\
\hline 12 & UF 3,4 & 8,03 & 7,87 & 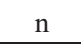 & 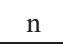 & $\mathrm{n}$ & $\mathrm{n}$ & $\mathrm{n}$ & $\mathrm{n}$ & $\mathrm{n}$ & $\mathrm{n}$ & 197 & 40 & 3,9 & 0,7 \\
\hline
\end{tabular}

Vzhledem k normou ČSN ISO 20761 definovaným kritériím kvality vody pro účely splachování toalet, při jejichž splnění jsou splněny také kritéria pro opětovné využití vody k zavlažování, budou v rámci diskuse výsledky srovnávány s limity pro zavlažování pouze při nesplnění podmínek k znovuvyužití vyčištěné vody k splachování toalet.

Normou ČSN ISO 20761 stanovený limit kvality vody k splachování toalet pro ukazatel pH splnily všechny testované vzorky.

Limit kvality vody $\mathrm{k}$ splachování toalet pro ukazatel barvy byl splněn pouze u prvních dvou testovaných vzorků (tedy čištěním PF), přičemž pro vzorek č. 11 (UF) nebyl ukazatel barvy stanoven. Výsledky vzorků č. 4-10 nesplnily ani normou ČSN ISO 20761 stanovené limity pro využití vyčištěné vody k zavlažování.

Vzorky č. 1-2 (PF) a č. 11 (UF) splnily limity pro splachování toalet ukazatele zákalu $\leq 2 \mathrm{NTU}$ (neboli ZF $\mathrm{F}_{(\mathrm{n})}$ ) stanovený ve Španělsku a USA, dále limity vymezující maximum $\leq 5$ NTU a medián $\leq 2$ NTU stanovené v Kanadě a Izraeli, a limit vymezující maximum $\leq 5$ NTU stanovený v Číně. Hodnota ukazatele zákalu ostatních vzorků přesáhla tyto stanovené hodnoty. Pouze testované vzorky č. 5 (PF) a č. 10 (MF) nesplnily požadovaný limit zákalu $\leq 10 \mathrm{mg} \cdot 1^{-1}$ pro zavlažování stanovený v Č́ně, částečně byly také splněny limity stanovené v Izraeli, ostatní limity pro hodnotu zákalu pro vyčiššené vody určené k zavlažování jsou shodné s omezeními pro splachování.

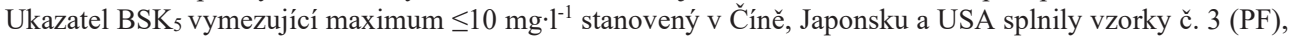
č. 6-9 (MF), č. 11 (UF). Limit pro ukazatel $\mathrm{BSK}_{5}$ vymezující maximum $\leq 20 \mathrm{mg} \cdot \mathrm{l}^{-1}$ a medián $\leq 10 \mathrm{mg} \cdot \mathrm{l}^{-1}$ splnily všechny vzorky.

Ukazatel NL vymezující maximum $\leq 10 \mathrm{mg} \cdot \mathrm{l}^{-1}$ stanovené ve Španělsku splnily pouze vzorky č. 8-10 (MF), č. 11 (UF). Limit pro ukazatel NL stanovený v Kanadě vymezující maximum $\leq 20 \mathrm{mg} \cdot \mathrm{l}^{-1}$ a medián $\leq 10 \mathrm{mg} \cdot \mathrm{l}^{-1} \mathrm{splnily}$ pouze vzorky č. 6-10 (MF) a č. 11 (UF). Limit pro hodnotu ukazatele NL pro vyčištěnou vodu určenou k zavlažování $\leq 30 \mathrm{mg} \cdot \mathrm{l}^{-1}$ nesplnil pouze vzorek č. 4 (PF).

V tabulce výsledků Tab. 3 se objevují také tenzidy, jejichž analýza byla provedena pouze pro rozbory ŠV a BV z testování v reálných podmínkách rodinného domu, kde oproti testování $\mathrm{PF}$ v laboratorních podmínkách pro čištění ŠV pouze ze sprchování, byly na vstupu do čistícího procesu zaústěny také odpadní vody z praček a koupelen, kde je předpokládán také výskyt pracích prostředků a prostředků pro úklid domácností. Ukazatel obsahu tenzidů ve vzorcích odpadní vody není normou ČSN ISO 20761 definován a je pouze informativní. 
Opětovné využití filtračních technologií PF vykázalo značné nesplnění sledovaných ukazatelů kvality vody na výstupu z technologického procesů čištění šedé vody. Pro zajištění vyšší účinnosti pro využití této technologie lze přistoupit změnou filltračního lože, prrípadně zavedením pravidelných pracích cyklů pískového fíltru. Při testování filtrační technologie MF byla předpokládána vyšší účinnost čištění vzhledem k možnosti separace menších částic. Technologie MF však rovněž nesplnila stanovené limity v plném rozsahu i po provedené fyzikální a chemické regeneraci membrán. Stále probíhající testování třetí etapy, tedy aplikace technologie UF pro čištění šedé vody $\mathrm{v}$ rámci reálné aplikace $\mathrm{v}$ rodinném domě vykazuje prozatím plné splnění stanovených limitů.

\section{ZÁVĚR}

V rámci př́spěvku byly představeny vybrané filtrační technologie určené $\mathrm{k}$ čištění šedých odpadních vod k jejich následnému využití pro nepitné účely. Pro ověření vhodnosti využití pískové filtrace, membránové mikrofiltrace a membránové ultrafiltrace čištění šedých odpadních vod k následnému využití vyčištěné bílé vody pro splachování toalet bylo provedeno jejich testování. Tento příspěvek byl zaměřen na představení získaných výsledků fyzikální a chemické analýzy vzorků a jejich srovnání s kritérii kvality bílé vody definovanými platnou legislativou.

Testování filtračních technologií proběhlo ve třech etapách. První etapa, testování pískové filtrace, proběhlo v laboratoři výzkumného centra AdMaS. Druhá etapa, testování mikrofiltrační membrány, proběhlo v reálných podmínkách rodinného domu. Testování třetí etapy, tedy aplikace ultrafiltrační membránové jednotky pro čištění šedé vody v reálných podmínkách rodinného domu, v současné době probíhá. Ukončení třetí etapy je plánováno do konce roku 2021.

\section{Poděkování}

Tento článek byl vytvořen s finanční podporou TA ČR v rámci řešení projektu TJ02000190 Získávání a využití tepelné energie z odpadní vody v kombinaci s využitím vyčištěné vody, dále s podporou juniorského Specifického výzkumu Vysokého učení technického v Brně v rámci řešení projektu FAST-J-21-7476 Aktuální přístupy k čištění odpadních vod.

\section{Použité zdroje}

[1] MRŇOVÁ, Z. Environmentální certifikace budov - situace v České republice. TZB-info [online]. 2021, 30.4.2021, 2021. ISSN 1801-4399. Dostupné z: https://stavba.tzb-info.cz/nizkoenergetickestavby/22180-environmentalni-certifikace-budov-situace-v-ceske-republice

[2] VELIKOVSKÁ, K.; MRAVCOVÁ, L.; ŠEVELA, P.; POLÁŠEK, P.; RAČEK, J.; HLAVÍNEK, P.; ŠVÁBOVÁ, M. Laboratorní testování účinnosti čištění a rekuperace tepelné energie šedé vody pro opětovné využití. Vodní hospodářství, 2021, roč. 71, č. 6, s. 3-11. ISSN: 1211-0760.

[3] ČSN ISO 20761. (2020). Opětovné využití vody v městských oblastech - Směrnice pro hodnocení bezpečnosti opětovného využití vody - Hodnocené ukazatele a metody (01.04.2020). Česká technická norma ( $\breve{C S N})$

[4] PIDOU, M.: Hybrid membrane processes for water reuse, Cranfield university, School of Applied Science, Department of Suistainable Systems, Centre for Water Science, PhD Thesis, 2006, supervisor: Dr. Bruce Jefferson.

[5] RAČEK, J. Metodika návrhu systému využití šedých vod ve vybraných objektech. Brno, 2016. 198 s., 2 přílohy, Dizertační práce. Vysoké učení technické v Brně, Fakulta stavební, Ústav vodního hospodářství obcí. Vedoucí práce doc. Ing. Jaroslav Raclavský, Ph.D.

[6] MINNESOTA RURAL WATER ASSOCIATION. (2001). Chapter19: Membrane Filtration. Minnesota Water Works Operations Manual, 1-12. Retrieved from http://www.mrwa.com/WaterWorksMnl/Chapter 19 Membrane Filtration.pdf

[7] PITTER, P. (2009). Hydrochemie (4., aktualiz. vyd). Vydavatelství VŠCHT Praha. 